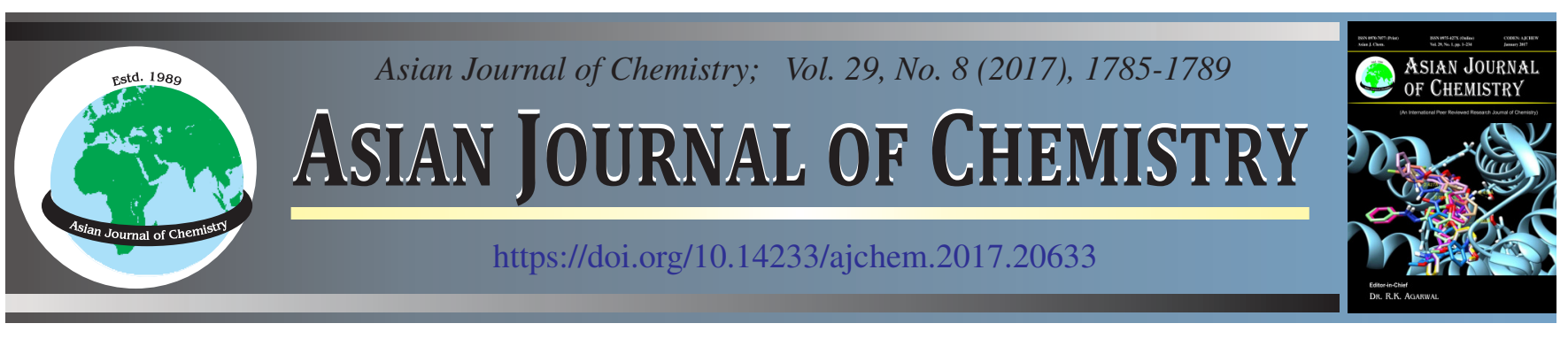

\title{
Removal of Lead(II) from Aqueous Solutions Using Sida rhombifolia as Biosorbent
}

Avis Tresa Babu, E. Shiju, K.E. Rakesh, E. Sreejina and Rosy Antony*

Post Graduate \& Research Department of Chemistry, Nirmalagiri College, Kannur-670 701, India

*Corresponding author: E-mail: drrosy.antony3@gmail.com

The weed Sida rhombifolia has been used as a biosorbent for removing lead ions from aqueous solution. The biosorption capacity tests were performed on an equilibrium batch basis to study the effects of contact time (10-120 min), temperature $\left(30-60{ }^{\circ} \mathrm{C}\right)$, initial metal ion concentration $(10-90 \mathrm{mg} / \mathrm{L})$, agitation speed $(50-250 \mathrm{rpm})$, biomass dosage $(50-500 \mathrm{mg})$ and retention volume $(25-150 \mathrm{~mL})$. The thermodynamic parameters indicated that the biosorption was a spontaneous and endothermic process. The pseudo second-order model described the kinetic data very well. The isotherm studies showed that the equilibrium data fits best with Temkin model.

Keywords: Sida rhombifolia, Biosorption, Lead(II).

\section{INTRODUCTION}

Industrial effluents contain a number of heavy metals and are usually discharged into water bodies. These heavy metals are non-biodegradable and tend to accumulate in the food chain and could damage normal physiological activity and endanger human life [1]. Lead is such a heavy metal which is leached out from service pipes and contaminates the drinking water. Its other sources are tetra ethyl lead from automobile exhausts, effluents of battery, paint and glass industries. Major health effects due to lead poisoning are nervous breakdown, weakness, headache, brain damage and behavioural disorders [2].

Several methods have been used for removal of heavy metal ions from aqueous phase such as precipitation, reverse osmosis, filtration, coagulation, solvent extraction and adsorption [3-6]. Adsorption of heavy metals using biomass is emerging as a promising process because of the low cost, high efficiency, ease of operation, regeneration of biosorbent and possibility of metal recovery [7-10]. The present study aims at evaluating the biosorption potential of the weed Sida rhombifolia (SR) for the removal of lead(II) from aqueous solution. The adsorption capacity tests were performed on an equilibrium batch basis and the parameters such as temperature, contact time, retention volume, biosorbent dose, initial metal ion concentration and agitation speed were optimized. Thermodynamics, kinetics and equilibrium isotherm modeling of biosorption process were studied.

\section{EXPERIMENTAL}

Preparation of biosorbent: The plant species Sida rhombifolia of uniform size, were collected, washed, dried powdered, sieved and characterized by XRD. It was found to be almost amorphous (Fig. 1).

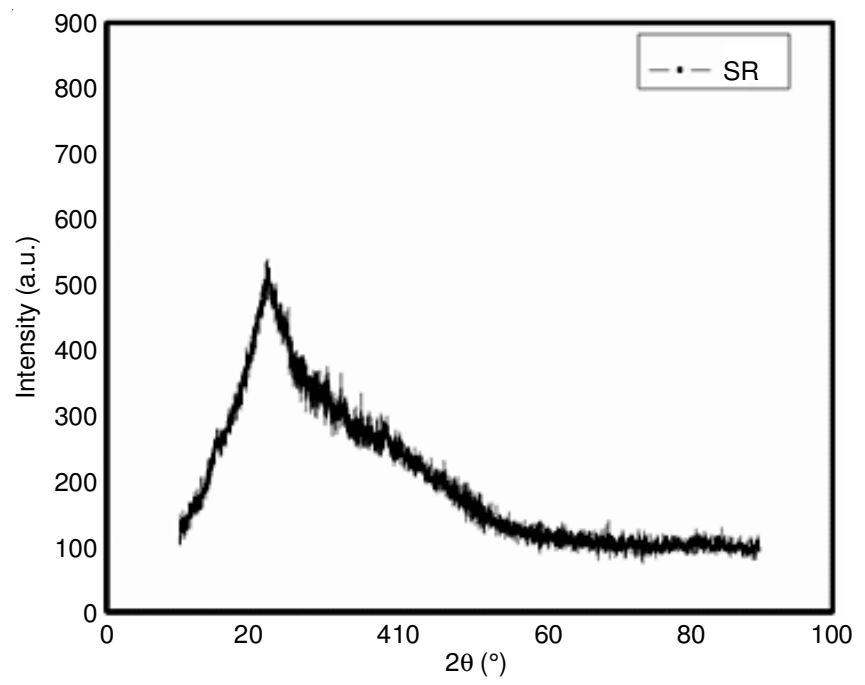

Fig. 1. XRD of biosorbent

Preparation of metal ion solution: Stock solution of $\mathrm{Pb}$ (II) containing $1000 \mathrm{mg} / \mathrm{L}$ of analytical grade lead(II) nitrate was prepared. 
Biosorption experiments: Batch adsorption experiments were carried out to investigate the effect of temperature, contact time, biosorbent dose, initial metal ion concentration, retention volume and agitation speed on the adsorption of $\mathrm{Pb}$ (II) on Sida rhombifolia. The concentrations of metal solutions before and after sorption were determined by atomic absorption spectrophotometer (AAS, Metrohm, Switzerland; model 797).

The amount of $\mathrm{Pb}$ (II) biosorbed by Sida rhombifolia $(\mathrm{mg} / \mathrm{g}$ ) after time $\mathrm{t}$ and at equilibrium, $\mathrm{q}_{\mathrm{t}}$ and $\mathrm{q}_{\mathrm{e}}$ were calculated using eqns. 1 and 2, respectively.

$$
\begin{aligned}
& \mathrm{q}_{\mathrm{t}}=\left(\mathrm{C}_{0}-\mathrm{C}_{\mathrm{t}}\right) \mathrm{V} / \mathrm{M} \\
& \mathrm{q}_{\mathrm{e}}=\left(\mathrm{C}_{0}-\mathrm{C}_{\mathrm{e}}\right) \mathrm{V} / \mathrm{M}
\end{aligned}
$$

where $C_{t}(m g / L)$ and $C_{e}(m g / L)$ are the final concentrations of $\mathrm{Pb}$ (II) in the solution after a given contact time $\mathrm{t}$ and at equilibrium, respectively; $\mathrm{C}_{0}(\mathrm{mg} / \mathrm{L}), \mathrm{V}(\mathrm{L})$ and $\mathrm{M}(\mathrm{g})$ are the initial concentration of $\mathrm{Pb}(\mathrm{II})$, the solution volume and the mass of biosorbent used, respectively. The percent removal, $\mathrm{R}$ $(\%)$, was calculated as:

$$
\mathrm{R}=\left(\mathrm{C}_{0}-\mathrm{C}_{\mathrm{t}}\right) / \mathrm{C}_{0} \times 100
$$

Adsorption kinetics: Lagergren's pseudo-first-order model [11] (eqn. 4) and pseudo-second-order model [12] (eqn. 5) have been used to predict sorption kinetics. The pseudo-firstorder equation is generally applicable over the initial stages of the adsorption process whereas the pseudo-second-order equation predicts the behaviour over the whole range.

$$
\begin{gathered}
\log \left(\mathrm{q}_{\mathrm{e}}-\mathrm{q}_{\mathrm{t}}\right)=\log \mathrm{q}_{\mathrm{e}}-\left(\mathrm{k}_{\mathrm{l}} / 2.303\right) \mathrm{t} \\
\mathrm{t} / \mathrm{q}_{\mathrm{t}}=1 / \mathrm{k}_{2} \mathrm{q}_{\mathrm{e}}^{2}+\left(1 / \mathrm{q}_{\mathrm{e}}\right) \mathrm{t}
\end{gathered}
$$

where $\mathrm{k}_{1} \min ^{-1}$ is the rate constant of pseudo-first-order adsorption, $\mathrm{k}_{2} \mathrm{~g} \mathrm{mg}^{-1} \mathrm{~min}^{-1}$ is the rate constant of pseudo-secondorder adsorption.

Intra-particle diffusion model: In order to investigate the mechanism of the lead adsorption onto Sida rhombifolia, intraparticle diffusion mechanism has been studied. According to Weber and Morris [13]:

$$
\mathrm{q}_{\mathrm{t}}=\mathrm{kp}_{\mathrm{i}} \mathrm{t}^{1 / 2}+\mathrm{C}_{\mathrm{i}}
$$

where $\mathrm{kp}_{\mathrm{i}}\left(\mathrm{mg} \mathrm{g}^{-1} \mathrm{~min}^{-1 / 2}\right)$, the rate parameter of stage $\mathrm{i}$, is obtained from the slope of the straight line of $\mathrm{q}_{\mathrm{t}}$ versus $\mathrm{t}^{1 / 2}$ whereas $\mathrm{C}_{\mathrm{i}}$ is the intercept of the plot.

Equilibrium studies: Adsorption experiments were carried out by adding a fixed amount of sorbent $(0.25 \mathrm{~g} / 75 \mathrm{~mL})$ to different initial metal ion concentrations $(10-90 \mathrm{mg} / \mathrm{L})$ at $30{ }^{\circ} \mathrm{C}$ with $150 \mathrm{rpm}$ for $180 \mathrm{~min}$ to ensure equilibrium. At time $\mathrm{t}=0$ and equilibrium, the metal concentrations were measured by AAS. The adsorption efficiency at equilibrium, $\mathrm{q}_{\mathrm{e}}(\mathrm{mg} / \mathrm{g})$, was calculated by eqn. 2 .

\section{RESULTS AND DISCUSSION}

Effect of biomass dosage: The effect of biomass dosage on biosorption of heavy metal is shown in Fig. 2. The percentage removal increases with increase in biomass dosage. This can be expected because the higher the dose of biosorbents in the solution, the greater the availability of exchangeable sites for the ions. With increase in the biomass dosage partial aggregation occurs which reduces the effective surface area for sorption [14]. Hence the optimum dosage was selected as 250 $\mathrm{mg}$ for further experiments.

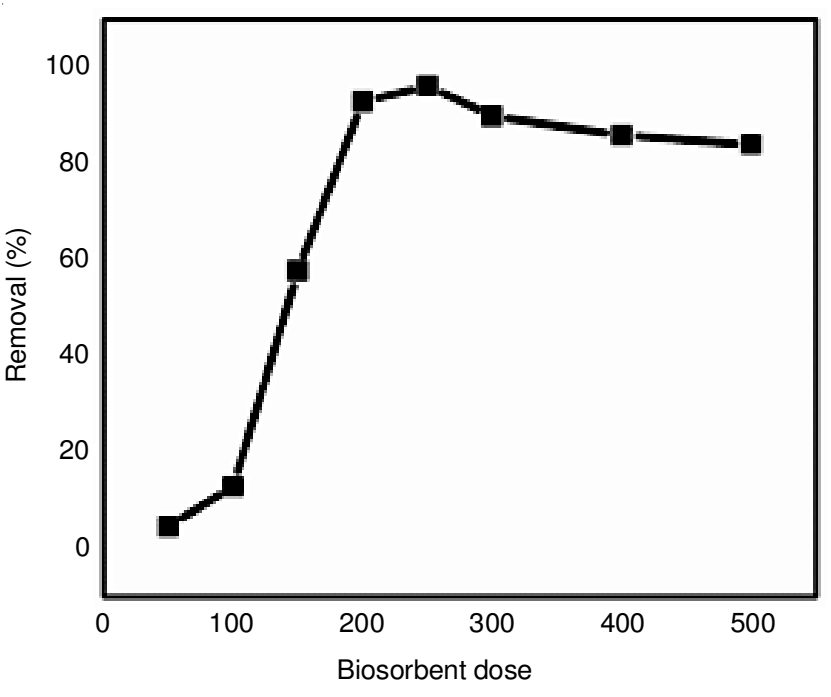

Fig. 2. Effect of biomass dose

Effect of contact time: The effect of contact time on biosorption of $\mathrm{Pb}(\mathrm{II})$ onto leaf biomass is shown in Fig. 3. The $\mathrm{Pb}(\mathrm{II})$ binding capacity is assumed to be proportional to the number of active sites occupied on the sorbent [15]. 95.2\% of the metal was found to be adsorbed within $10 \mathrm{~min}$.

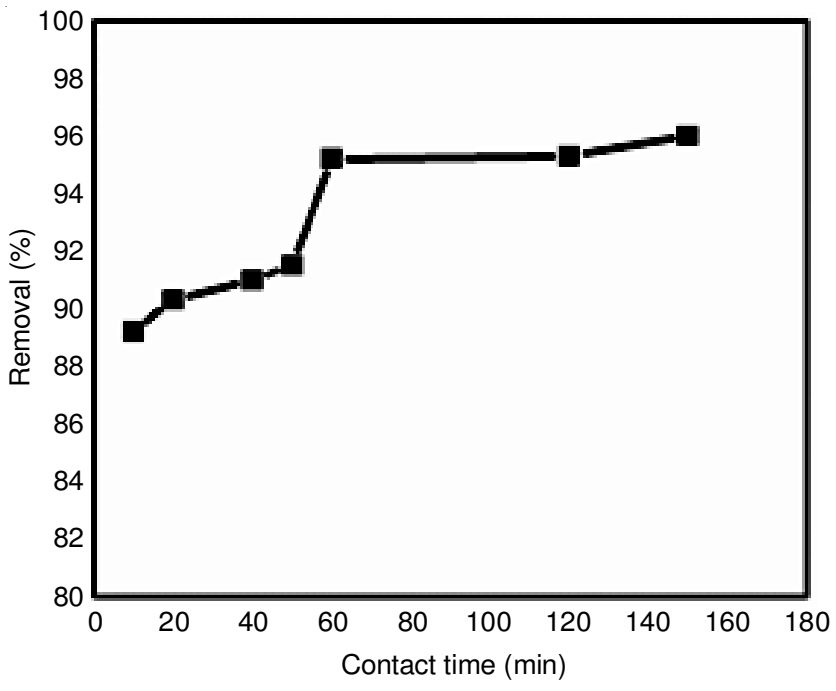

Fig. 3. Effect of contact time

Effect of temperature on biosorption: The influence of temperature on biosorption was investigated at 30, 40 and $60{ }^{\circ} \mathrm{C}$. The results indicated an increase in biosorption capacity with increasing temperature (Fig. 4). This may be attributed to either increase in the number of active sites available for biosorption or due to decrease in the boundary layer thickness surrounding the biosorbent, so that the mass transfer resistance of biosorbate in the boundary layer decreases. The observed increase in biosorption capacity with increase in temperature is indicative of an endothermic process.

Effect of initial $\mathbf{P b}$ concentration: Fig. 5 shows the variation of percentage removal with different initial metal ion concentrations. Up to $50 \mathrm{mg} / \mathrm{L}$, the sorption efficiency increases and after that a steady state is reached which may be due to the saturation of available sites on the cell surface preventing further adsorption of metal ions [16]. 


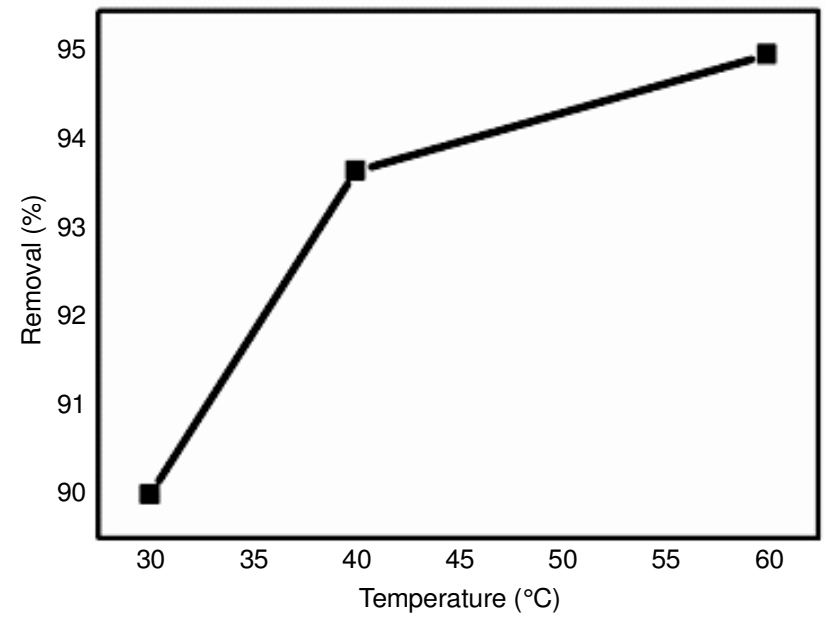

Fig. 4. Effect of temperature

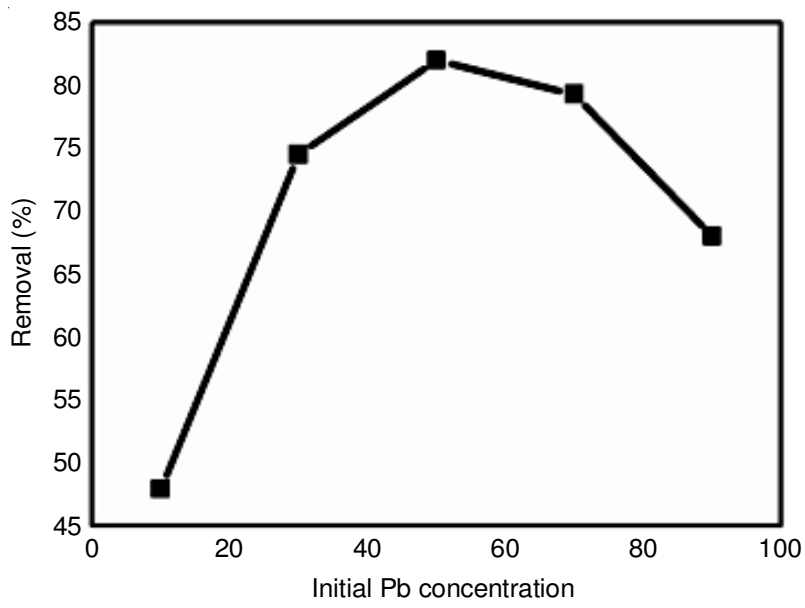

Fig. 5. Effect of initial $\mathrm{Pb}$ concentration

Effect of agitation speed: The effect of agitation speed in determining the sorption efficiency of leaf biomass was also tested at different rpm (50-250) (Fig. 6). The main mechanisms of binding include ionic interactions and complex formations between metal cations and ligands on the surface of the plants [17]. Hence effective mixing of the particles with the metal containing solution is an effective mechanism to increase the efficiency.

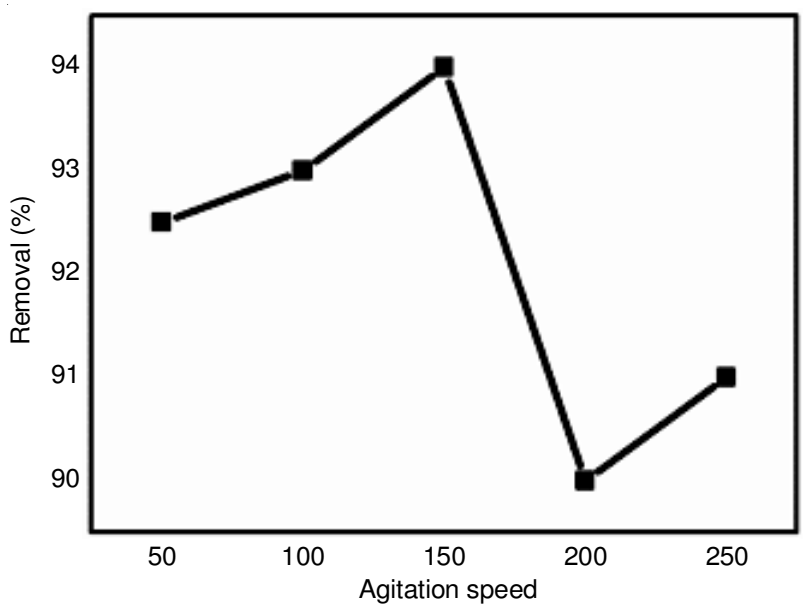

Fig. 6. Effect of agitation speed (rpm)
Effect of retention volume: The effect of different retention volume was studied in the range $25-150 \mathrm{~mL}$ and is shown in Fig. 7. The retention volume was optimized as $75 \mathrm{~mL}$.

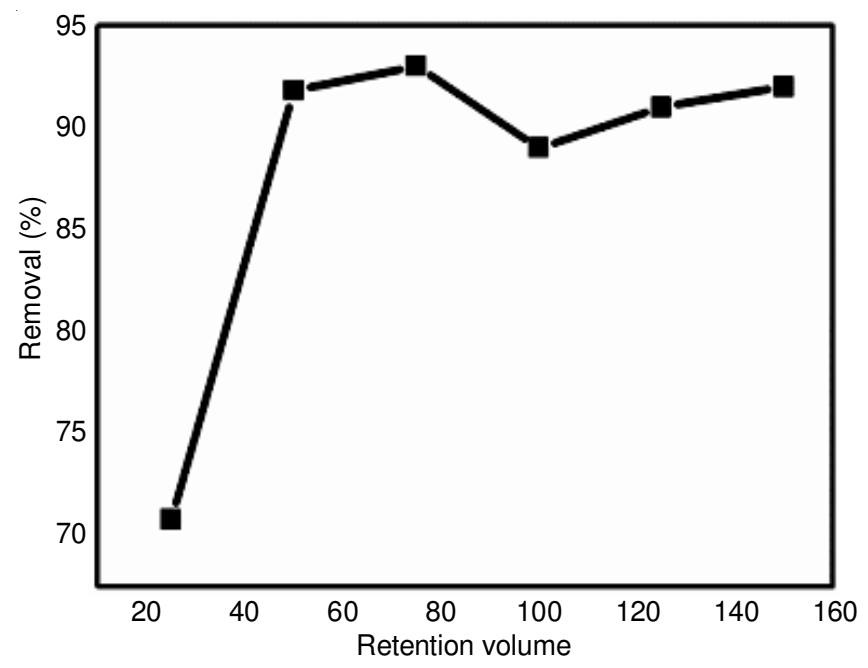

Fig. 7. Effect of retention volume

Adsorption kinetics: The kinetic behaviour of $\mathrm{Pb}$ adsorption onto Sida rhombifolia was studied with different initial $\mathrm{Pb}$ concentrations. At the initial stage of the adsorption process, the rate of $\mathrm{Pb}$ adsorption was very rapid and reaches equilibrium within 10 min of contact. The pseudo-first-order model data do not fall on straight lines for most initial concentrations indicating that this model is not suited. The experimental kinetic data were further analyzed using the pseudo-secondorder model. By plotting $\mathrm{t} / \mathrm{q}_{\mathrm{t}}$ versus $\mathrm{t}$ straight lines are obtained (Fig. 8).

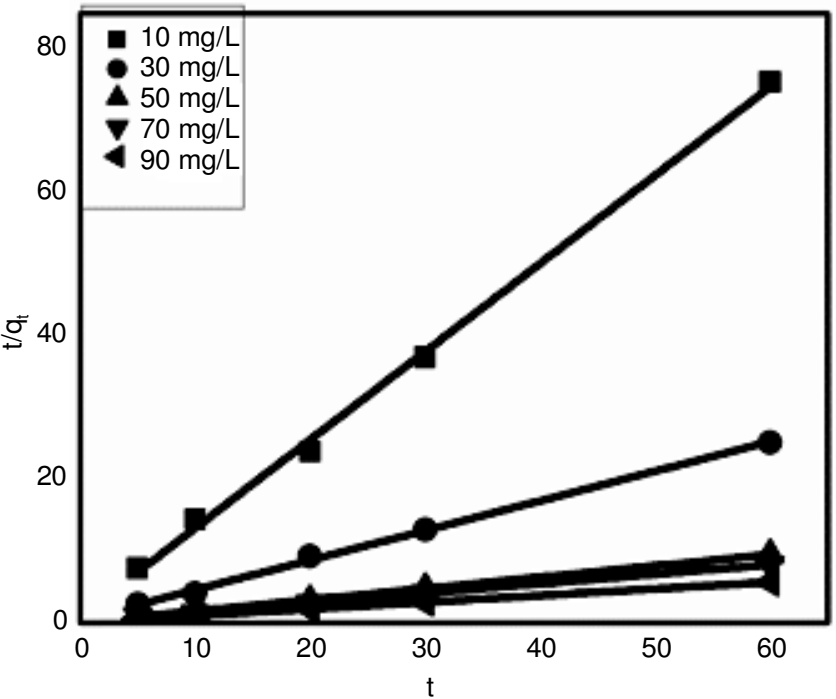

Fig. 8. Plots of (a) Pseudo second order kinetic model for Pb adsorption by Sida rhombifolia at different initial $\mathrm{Pb}$ concentrations

The calculated adsorption capacity $\mathrm{q}_{\mathrm{e}}$ (cal) was quite agreeable with $\mathrm{q}_{\mathrm{e}}(\exp )$ values, where $\mathrm{R}^{2}$ values are close to 1 (Table-1). It confirms the applicability of the pseudo secondorder equation to the biosorption process.

To explain the diffusion mechanism the kinetic results were then analyzed by the intraparticle diffusion model. As 


\begin{tabular}{ccccc}
\hline \multicolumn{5}{c}{ TABLE-1 } \\
PSEUDO SECOND ORDER KINETIC PARAMETERS \\
\hline Initial & \multicolumn{4}{c}{ Pseudo-second-order kinetics at } \\
conc. & \multicolumn{4}{c}{$30^{\circ} \mathrm{C}$ (Sida rhombifolia) } \\
(mg/L) & $\mathrm{K}_{2}$ & $\mathrm{q}_{\text {e(exp) }}$ & $\mathrm{q}_{\text {e(cal) }}$ & $\mathrm{R}^{2}$ \\
\hline 10 & 1.640 & 0.837 & 0.813 & 0.998 \\
30 & 0.360 & 2.448 & 2.415 & 0.998 \\
50 & 0.425 & 6.342 & 6.369 & 0.999 \\
70 & 0.111 & 7.293 & 7.570 & 0.998 \\
90 & 0.127 & 10.413 & 10.700 & 0.999 \\
\hline
\end{tabular}

seen from Fig. 9, the plots were not linear throughout, implying that in addition to intraparticle diffusion, boundary layer diffusion also occur [18].

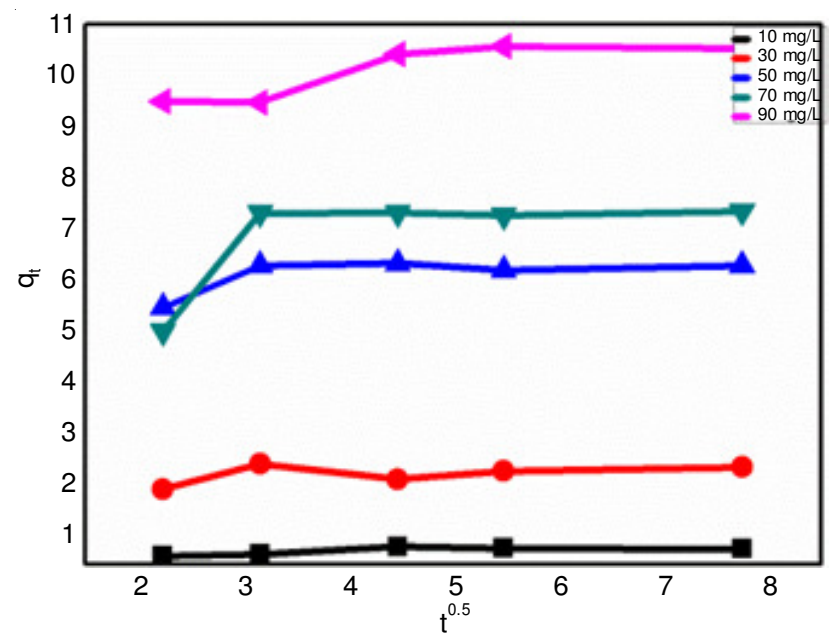

Fig. 9. Intraparticle diffusion plot for adsorption of lead on Sida rhombifolia for different initial lead concentrations

Equilibrium isotherms: The linear form of Temkin isotherm model [19] is

$$
\mathrm{q}_{\mathrm{e}}=\mathrm{B} \ln \mathrm{A}+\mathrm{B} \ln \mathrm{C}_{\mathrm{e}}
$$

where $\mathrm{B}=\mathrm{RT} / \mathrm{b}$. $\mathrm{B}$ is the Temkin constant related to heat of sorption $(\mathrm{J} / \mathrm{mol})$; A is the Temkin isotherm constant $(\mathrm{L} / \mathrm{g}), \mathrm{R}$ the gas constant $(8.314 \mathrm{~J} / \mathrm{mol} \mathrm{K})$ and $\mathrm{T}$ is the absolute temperature $(\mathrm{K})$. By plotting $\mathrm{q}_{\mathrm{e}}$ versus $\ln \mathrm{C}_{\mathrm{e}}$, $\mathrm{A}$ and $\mathrm{B}$ are obtained from slope and intercept. The adsorption data for lead on Sida rhombifolia was subjected to regression analysis to fit the Temkin isotherm model (Fig. 10). With calculated values of A $=0.1429 \mathrm{~L} / \mathrm{g}$ and $\mathrm{B}=4.5257 \mathrm{~J} / \mathrm{mol}$, the isotherm fits quite well with the experimental data (coefficient of correlation, $\mathrm{R}^{2}$ $=0.923$ ).

Biosorption thermodynamics: Thermodynamic parameters such as Gibbs free energy change $\left(\Delta \mathrm{G}^{\circ}\right)$, enthalpy change $\left(\Delta \mathrm{H}^{\circ}\right)$ and entropy change $\left(\Delta \mathrm{S}^{\circ}\right)$ were estimated using equilibrium constants determined at different temperatures and were employed to elucidate the biosorption process. The equilibrium distribution coefficient $\left(\mathrm{K}_{\mathrm{d}}\right)$ is related to $\Delta \mathrm{H}^{\circ}$ and $\Delta \mathrm{S}^{\circ}$ as given by eqn. 8 .

$$
\ln \mathrm{K}_{\mathrm{d}}=\Delta \mathrm{S}^{\circ} / \mathrm{R}-\Delta \mathrm{H}^{\circ} / \mathrm{RT}
$$

where $\mathrm{T}(\mathrm{K})$ the absolute temperature. The values of $\Delta \mathrm{H}^{\circ}$ and $\Delta \mathrm{S}^{\circ}$ were determined from the slope and intercept of Van't Hoff plot of $\ln \mathrm{K}_{\mathrm{d}}$ versus $1 / \mathrm{T}$ shown in Fig. 11. The values of $\mathrm{K}_{\mathrm{d}}$ were obtained from eqn. (9).

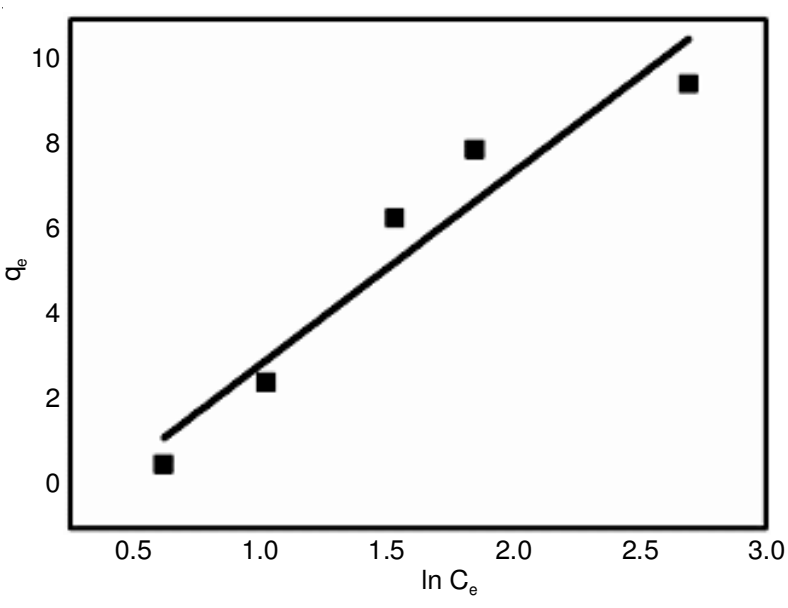

Fig. 10. Temkin adsorption isotherm

$$
\mathrm{K}_{\mathrm{d}}=\mathrm{C}_{\mathrm{ad}, \mathrm{e}} / \mathrm{C}_{\mathrm{e}}
$$

where $\mathrm{C}_{\text {ad,e }}(\mathrm{mg} / \mathrm{L})$ is the concentration of $\mathrm{Pb}(\mathrm{II})$ on Sida rhombifolia at equilibrium and $\mathrm{C}_{\mathrm{e}}(\mathrm{mg} / \mathrm{L})$ the equilibrium concentration of $\mathrm{Pb}$ (II) in solution. Subsequently, the values of $\Delta \mathrm{G}^{\circ}$ were calculated from eqn. 10 .

$$
\Delta \mathrm{G}^{\circ}=\Delta \mathrm{H}^{\circ}-\mathrm{T} \Delta \mathrm{S}^{\circ}
$$

\begin{tabular}{|c|c|}
\hline \multicolumn{2}{|c|}{$\begin{array}{c}\text { TABLE-2 } \\
\text { THERMODYNAMIC PARAMETERS FOR THE } \\
\text { BIOSORPTION OF Pb(II) ONTO Sida rhombifolia }\end{array}$} \\
\hline \multicolumn{2}{|c|}{ Thermodynamic parameters } \\
\hline$\Delta \mathrm{H}^{\circ}(\mathrm{kJ} / \mathrm{mol})$ & 369.219 \\
\hline$\Delta \mathrm{S}^{\circ}(\mathrm{kJ} / \mathrm{mol})$ & 1295.3 \\
\hline \multicolumn{2}{|l|}{$\Delta \mathrm{G}^{\circ}(\mathrm{kJ} / \mathrm{mol})$} \\
\hline at $303 \mathrm{~K}$ & -23.265 \\
\hline at $313 \mathrm{~K}$ & -36.219 \\
\hline at $333 \mathrm{~K}$ & -62.125 \\
\hline
\end{tabular}

The values of $\Delta \mathrm{G}^{\circ}, \Delta \mathrm{H}^{\circ}$ and $\Delta \mathrm{S}^{\circ}$ obtained are given in Table-2. The negative values of $\Delta \mathrm{G}^{\circ}$ at various temperatures shows that the biosorption process was feasible and spontaneous.

The values of $\Delta \mathrm{G}^{\circ}$ decreased with increase in temperature. The order of magnitude of $\Delta \mathrm{H}^{\circ}$ suggests that the biosorption is of the diffusion type. The positive value of $\Delta \mathrm{S}^{\circ}$ suggests increased randomness at the solid/solution interface during the biosorption process.

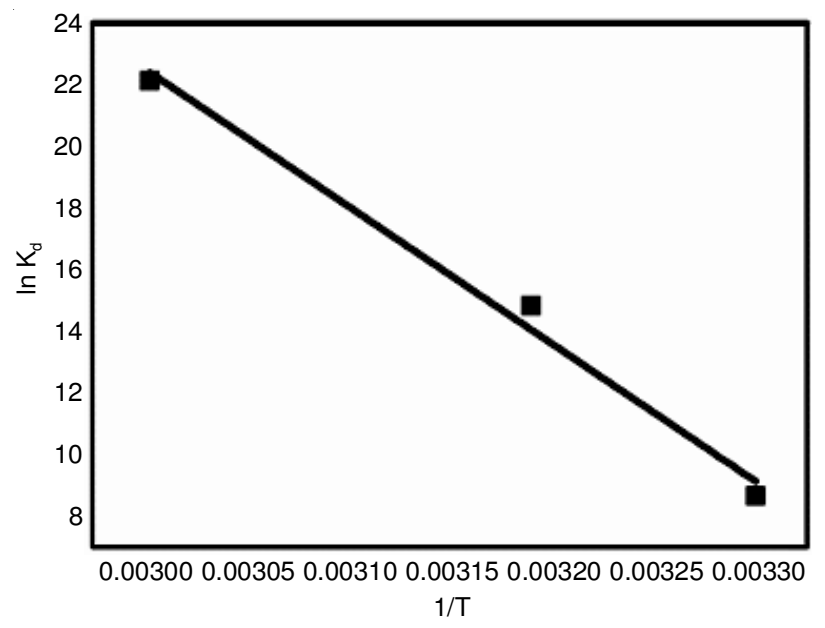

Fig. 11. van’t Hoff plot 
Table- 3 shows the percentage removal of lead ions using some plants and weeds as biosorbents. Of these Sida rhombifolia shows the highest value for adsorption efficiency. As Sida rhombifolia is a local weed, abundant in Kerala, we studied its utility for adsorption of organic dyes also. It has been found that the adsorption efficiency of Sida rhombifolia for methylene blue and lead ions are comparable. We converted this waste biomass (which is an unwanted weed grown in cultivation fields) into a useful biosorbent for effluent treatment.

\begin{tabular}{lcc}
\multicolumn{3}{c}{ TABLE-3 } \\
COMPARISON OF BIOSORPTION CAPACITIES OF \\
Pb(II) IONS BY DIFFERENT BIOSORBENTS \\
\hline \multicolumn{1}{c}{ Biosorbent } & $\begin{array}{l}\text { Removal } \\
\text { of Pb(II) }\end{array}$ & Ref. \\
& ions (\%) & \\
\hline Canna indica & 84.00 & {$[20]$} \\
Eichhornia crassipes & 93.00 & {$[20]$} \\
Eupatorium adenophorum spreng & 90.45 & {$[21]$} \\
Carica papaya leaf & 89.80 & {$[22]$} \\
Lantana camara L. Biomass (ACL) & 93.00 & {$[23]$} \\
Lantana camara L. Biomass (ACS) & 79.00 & {$[23]$} \\
Tea leaves & 92.00 & {$[24]$} \\
Chlamydomonas reinhardtii & 40.00 & {$[25]$} \\
Sida rhombifolia (SR) & 94.47 & Present study \\
\hline
\end{tabular}

\section{Conclusion}

Sida rhombifolia is used as a biosorbent for the removal of $\mathrm{Pb}$ (II) from aqueous solution. The parameters such as contact time, initial concentration of $\mathrm{Pb}(\mathrm{II})$, agitation speed, retention volume and biosorbent dose were optimized as $10 \mathrm{~min}, 50 \mathrm{mg} / \mathrm{L}$, $150 \mathrm{rpm}, 75 \mathrm{~mL}$ and $250 \mathrm{mg}$, respectively. The thermodynamic study was found to be endothermic. The adsorption kinetics can be predicted by pseudo-second-order model. Temkin isotherm model was found to be most suitable in describing the equilibrium of the biosorption process. The results of the present investigation indicate that the Sida rhombifolia has a potential for use in removing lead from aqueous solutions.

\section{REFERENCES}

1. D. Bulgariu and L. Bulgariu, Bioresour. Technol., 129, 374 (2013); https://doi.org/10.1016/j.biortech.2012.10.142.

2. W. Kitobo, S. Gaydardzhiev, J. Frenay, D. Bastin and I. Ndala, Sep. Sci. Technol., 45, 535 (2010); https://doi.org/10.1080/01496390903529869.

3. A. Janin, J.F. Blais, G. Mercier and P. Drogui, J. Hazard. Mater, 169, 1099 (2009);

https://doi.org/10.1016/j.jhazmat.2009.04.066.
4. S. Nii, S. Okumura, T. Kinoshita, Y. Ishigaki, K. Nakano, K. Yamaguchi and S. Akita, Sep. Purif. Technol., 73, 250 (2010); https://doi.org/10.1016/j.seppur.2010.04.009.

5. L. Canet, M. Ilpide and P. Seta, Sep. Sci. Technol., 37, 1851 (2002); https://doi.org/10.1081/SS-120003047.

6. E. Katsou, S. Malamis and M. Loizidou, Bioresour. Technol., 102, 4325 (2011); https://doi.org/10.1016/j.biortech.2010.10.118.

7. K. Vijayaraghavan and R. Balasubramanian, J. Environ. Chem. Eng., 1, 473 (2013);

https://doi.org/10.1016/j.jece.2013.06.017.

8. S. Bunluesin, M. Kruatrachue, P. Pokethitiyook, S. Upatham and G.R. Lanza, J. Biosci. Bioeng., 103, 509 (2007); https://doi.org/10.1263/jbb.103.509.

9. S.S. Baral, S.N. Das, P. Rath, G. Roy Chaudhury and Y.V. Swamy, Chem. Ecol., 23, 105 (2007); https://doi.org/10.1080/02757540701197697.

10. F. Boudrahem, F. Aissani-Benissad and A. Soualah, J. Chem. Eng. Data, 56, 1804 (2011); https://doi.org/10.1021/je100770j.

11. Y. Guo, J. Qi, S. Yang, K. Yu, Z. Wang and H. Xu, Mater. Chem. Phys., 78, 132 (2003); https://doi.org/10.1016/S0254-0584(02)00302-4.

12. K. Ravikumar, S. Krishnan, S. Ramalingam and K. Balu, Dyes Pigments, 72, 66 (2007); https://doi.org/10.1016/j.dyepig.2005.07.018.

13. W. Weber and J. Morris, J. Sanitary Eng. Div. Proceed. Am. Soc. Civil Eng., 89, 31 (1963).

14. S. Karthikeyan, R. Balasubramanian and C.S.P. Iyer, Bioresour. Technol., 98, 452 (2007); https://doi.org/10.1016/j.biortech.2006.01.010.

15. M. Hashim, Chem. Eng. J., 97, 249 (2004); https://doi.org/10.1016/S1385-8947(03)00216-X.

16. B. Volesky, Hydrometallurgy, 71, 179 (2003); https://doi.org/10.1016/S0304-386X(03)00155-5.

17. K.A. Hima, R.R. Srinivasa, S.S. Vijaya, S.B. Jayakumar, V. Suryanarayana and P. Venkateshwar, Afr. J. Biotechnol., 6, 2924 (2007); https://doi.org/10.5897/AJB2007.000-2461.

18. Y. Cheung, Y.S. Szeto and G. McKay, Bioresour. Technol., 98, 2897 (2007); https://doi.org/10.1016/j.biortech.2006.09.045.

19. M.J. Temkin and V. Pyzhev, Acta Physiochem. USSR, 12, 217 (1940).

20. D. Archana, D. Savita and C. Goswami, J. Bioremediat. Biodegrad., 6, 3 (2015).

21. S. Guo, W. Li, L. Zhang, J. Peng, H. Xia and S. Zhang, Process Saf. Environ. Prot., 87, 343 (2009); https://doi.org/10.1016/j.psep.2009.06.003.

22. D. Raju, V. Rao, P. Prasad and N. Babu, Int. J. Eng. Sci. Adv. Technol., 6, 1577 (2012)

23. V.K. Saini, S. Suthar, C. Karmveer and K. Kumar, J. Chem., Article ID 5612594 (2017); https://doi.org/10.1155/2017/5612594.

24. B. Shrestha, J. Kour, P.L. Homagai, M.R. Pokhrel and K.N. Ghimire, Adv. Chem. Eng. Sci., 3, 178 (2013); https://doi.org/10.4236/aces.2013.33022.

25. R. Flouty and G. Estephane, J. Environ. Manage., 111, 106 (2012); https://doi.org/10.1016/j.jenvman.2012.06.042. 